\title{
Food additives reduce lactic acid bacterial growth in culture medium and in meat products, increasing product shelf life
}

\section{Aditivos alimentares reduzem o crescimento de bactérias láticas em meio de cultura e em produtos cárneos, promovendo acréscimo da vida útil}

\author{
Cleonice Mendes Pereira Sarmento ${ }^{1 *}$; Eliane Colla ${ }^{1}$; Cristiane Canan ${ }^{1}$; \\ Francieli Dalcanton²; Glaúcia Maria Falcão de Aragão ${ }^{3}$
}

\begin{abstract}
The uncontrolled growth of lactic acid bacteria (LAB) in meat and meat products leads to product spoilage, and thus shortens product shelf life. Although food additives are known to decrease LAB growth, this effect has not been analyzed in detail. Here, a detailed analysis was performed of the effects of sodium chloride, sodium polyphosphate, sodium lactate, sodium nitrite/nitrate, and garlic on the growth of the Lactobacillus plantarum in culture medium. The results were used to design and test experimental formulations of meat products. Initially, the effect of food additives on L. plantarum was evaluated using a Fractional Factorial Design (FFD), followed by a Central Composite Rotatable Design (CCRD). The Modified Gompertz Model was adjusted to the growth curves to determine the Kinetic parameters of bacterial growth (logarithmic increase in the population, specific growth rate, and lag phase extension). Higher sodium lactate and sodium chloride levels had a negative impact on L. plantarum growth parameters $(\mathrm{p} \leq 0.05)$. Therefore, we designed experimental formulations of mortadella and smoked pork sausages containing 4\% sodium lactate $\left(\mathrm{w}^{-1}\right)$ and $2.4-3.5 \%$ sodium chloride $\left(\mathrm{W} \mathrm{w}^{-1}\right)$, and determined LAB growth from samples of stored products produced according to these formulations, in order to determine product shelf life. There was an increased lag phase of LAB growth for most experimental formulations. Also, the experimental smoked pork sausages had a longer shelf life, which was increased by at least 22 days, suggesting that the proposed formulation, with higher than standard lactate concentration, increased the product's shelf life.
\end{abstract}

Key words: Fractional factorial desing, Lactobacillus plantarum, sausage, sodium chloride, sodium lactate, sodium polyphosphate

\section{Resumo}

O rápido crescimento de bactérias láticas $(\mathrm{BAL})$ em carnes e produtos cárneos leva a deterioração, reduzindo sua vida útil. Embora os aditivos alimentares sejam conhecidos por diminuir o crescimento de BAL, este efeito não tem sido avaliado especificamente. Neste trabalho, foi realizada uma análise detalhada dos efeitos do cloreto de sódio, polifosfato de sódio, lactato de sódio, nitrito/nitrato de sódio e alho no crescimento de Lactobacillus plantarum, em meio de cultura. Os resultados foram utilizados para desenvolver e testar experimentalmente formulações de produtos cárneos. Inicialmente, o efeito

\footnotetext{
1 Profas, Universidade Tecnológica Federal do Paraná, UTFPR, Dept ${ }^{\circ}$ de Tecnologia de Alimentos, Medianeira Campus, Paraná, Brasil.E-mail: cleosarmento@utfpr.edu.br; ecolla@utfpr.edu.br; canan@utfpr.edu.br

2 Prof ${ }^{a}$, Universidade Comunitária da Região de Chapecó, UNOChapecó, Chapecó, Santa Catarina, Brasil. E-mail: fran_dal@ yahoo.com.br

3 Prof ${ }^{a}$, Universidade Federal de Santa Catarina, UFSC, Campus Universitário, Dept ${ }^{\mathrm{o}}$ de Engenharia Química e Engenharia de Alimentos, Florianópolis, SC, Brasil. E-mail: glaucia.aragao@ufsc.br

Author for correspondence
} 
dos aditivos alimentares sobre o crescimento de L. plantarum foi avaliado utilizando um Delineamento Fatorial Fracionário (DFF), seguido por um Delineamento Composto Central Rotacional (DCCR). O modelo de Gompertz Modificado foi ajustado às curvas de crescimento para determinar os parâmetros de cinetica de crescimento bacteriano . Níveis superiores de lactato de sódio e cloreto de sódio promoveram a diminuição dos parâmetros de crescimento para o L. plantarum $(\mathrm{p} \leq 0,05)$. Foram desenvolvidas formulações de mortadela e linguiça suína defumada, contendo lactato de sódio 4,0\% (w/w) e cloreto de sódio 2,4-3,5\% (w/w). Em seguida, as mesmas foram armazenadas para o acompanhamento da vida útil pela contagem de BAL. Observou-se um aumento na duração da fase lag das formulações avaliadas. Também foi observado que o aumento da concentração de lactato de sódio nas concentrações estudadas promoveu um aumento de 22 dias na vida útil da linguiça suína defumada.

Palavras-chave: Delineamento fatorial fracionário, Lactobacillus plantarum, embutidos, cloreto de sódio, polifosfato de sódio

\section{Introduction}

Meat is highly sensitive to microbial deterioration due to its high water activity, near neutral $\mathrm{pH}$, and high nutrient concentration (HUGAS, 1998). After processing, lactic acid bacteria (LAB) such as Carnobacterium piscicola, C. divergens, Lactobacillus sakei, L. viridescens, L. curvatus, L. plantarum, and Leuconostoc mesenteroides are often present in the initial meat microbiota. These microorganisms develop easily when meat is stored at low temperatures, either vacuum-packed or under a modified atmosphere (ARVANITOYANNIS; STRATAKOS, 2012).

While some metabolic products of LAB growth, like organic acids and bacteriocins, play an important role in food preservation (DABÉS et al., 2001), the uncontrolled growth of some LAB species leads to the spoilage of meat and meat products (ZHANG et al., 2009; AMMOR et al., 2005). Indeed, LAB were identified as the largest spoilage-causing population in vacuum-packed products, in products kept at a modified atmosphere, as well as in other processed meat products that were kept refrigerated (SAMELIS et al., 2000; KREYEN SCHMIDT et al., 2010; VERCAMMEN et al., 2011). In studies by, Viuda-Martos et al. (2010a, 2010b), mortadella manufactured according to a traditional formula including $2.5 \%$ sodium chloride $\left(\mathrm{w} \mathrm{w}^{-1}\right), 300 \mathrm{mg}$ $\mathrm{kg}^{-1}$ sodium tripolyphosphate, $500 \mathrm{mg} \mathrm{kg}^{-1}$ sodium ascorbate, $150 \mathrm{mg} \mathrm{kg}^{-1}$ sodium nitrite, spices, and orange dietary fiber did not undergo appreciable degradation when stored under different conditions (vacuum-packed, with modified atmosphere at 23 ${ }^{\circ} \mathrm{C}$, or in heat-sealed packs at $4{ }^{\circ} \mathrm{C}$ ) for 24 days. No enterobacteria or psychotropic bacteria were found in any of the treatments, regardless of packaging method or storage time. In all samples, the total counts of aerobic bacteria and LAB at the end of the experiment were below those observed in degraded products (as defined by their higher viscosity, color changes, and off-flavors). This result was probably due to the effectiveness of the cooking process, to the aseptic slicing process, as well as to the presence of sodium chloride in the products. Sodium chloride is one of the most frequently used ingredients in meat processing. It affects flavor and texture, and increases the product shelf life, due to its ability to reduce water activity. However, the amount of sodium chloride in processed meat products should be reduced for health reasons (RUUSUNEN; PUOLANNE, 2005).

In refrigerated poultry meat, Oliveira et al. (2005) found that aqueous garlic extract inhibited the growth of microbial contaminants (including facultative aerobic, mesophilic, and fecal coliforms) on the surface of poultry carcasses.

Organic salts are also commonly used to control the growth of undesirable microorganisms on stored food and meat products. While extensive research has examined the effects of lactate, acetate, and sorbate on the viability of pathogens such as Listeria monocytogenes and Salmonella spp. during refrigerated storage of vacuum-packed meat products dipped or sprayed with these chemicals 
(MBANDI; SHELEP, 2001; GLASS et al., 2002; NUNEZ DE GONZALEZ et al., 2004), little is known about the antimicrobial effects of organic salts on spoilage bacterial growth when these salts are incorporated in meat product formulations. Devlieghere et al. (2000) suggested that storage temperature, water activity, and sodium lactate percentage may influence L. plantarum growth on stored meat. Muench et al. (2008) reported that a mixture of $55.7 \%$ sodium lactate and $4 \%$ sodium diacetate, used at a concentration of $3 \%$, prevented spoilage of Natural Casing frankfurters (during a 15-week storage period at $3{ }^{\circ} \mathrm{C}$, in the absence of light), with no negative impact on quality.

Additional research is needed to further evaluate whethertheability oforganic saltstoinhibit the growth of food-spoiling bacteria such as LAB is associated with extended product shelf life. The evaluation of different combinations and concentrations of salts and additives against the growth of spoilage $\mathrm{LAB}$ in meat products - with the ultimate goal of extending meat products' shelf life - using powerful statistical methods such as DOE (Design of Experiments) and Predictive Microbiology has not been reported in the scientific literature. Only a limited number of studies have focused on the study of LAB growth in broth (DROSINOS et al., 2006; KHANIPOUR et al., 2014) for analysis of antagonistic and synergistic effects of salts and additives in meat products, which is the focus of this work. The need to guarantee microbiological safety and food quality led to the development of predictive microbiology tools (NAKASHIMA et al., 2000), such as the Modified Gompertz Model (a double exponential function that describes an asymmetric sigmoid curve) successfully applied by Slongo et al. (2009) to the study of LAB growth in ham, yielding adequate LAB growth curves. The aim of the current work was to evaluate the effect of different concentrations of sodium chloride, sodium lactate, sodium polyphosphate, sodium nitrite/ nitrate, and garlic on the growth of the LAB species L. plantarum in culture medium (MRS broth) and in two meat products, mortadella and smoked pork sausages, using a modified Gompertz model that was previously applied successfully to describe LAB growth in ham (SLONGO et al., 2009). L. plantarum was selected due to its importance in the spoilage of industrialized meat products (CAYRÉ et al., 2003; SALLAM et al., 2004; CAYRÉ et al., 2005; MATARAGAS et al., 2006; TODOROV et al., 2010). The results of the analysis of L. plantarum growth in culture medium were used to design meat formulations that would increase product shelf life.

\section{Material and Methods}

\section{Microorganism and cell culture methods}

In this work, we used lactic acid bacteria from the L. plantarum species (strain CCT 0580, ATCC 8014) obtained as lyophilized samples from the Collection of Tropical Cultures (CCT) of the André Tosello Foundation (Campinas, São Paulo, Brazil), which were rehydrated and routinely maintained in MRS (de Man, Rogosa and Sharpe) broth at $4{ }^{\circ} \mathrm{C}$. Prior to their use in growth monitoring experiments, bacterial cultures were subjected to reactivation in MRS broth by incubation for 7 hours at $35^{\circ} \mathrm{C}$.

Analysis of the effect of food additives on $L$. plantarum growth in MRS Broth

\section{Fractional factorial design (FFD)}

Initially, a fractional factorial design including $2^{5-1}$ trials plus three central points (19 runs) (RODRIGUES; IEMMA, 2005) was carried out to evaluate the effects of the concentration of sodium lactate (Purac, São Paulo, Brazil), sodium chloride $(\mathrm{NaCl})$, sodium polyphosphate, sodiumnitrite/nitrate (all from Clariant, São Paulo, Brazil), and garlic on the responses provided by the microbiological growth parameters (logarithmic increase in the population $[\mathrm{A}]$, exponential microbial growth rate $[\mathrm{m}]$, and lag phase extension $[\lambda$ ) of L. plantarum. The statistical design and the coded and real values 
for each variable are shown in Table 1. The levels of each factor were selected according to the concentrations of additives used in the meat product processing industry, and considering the maximum concentrations permitted by law (Regulation $\mathrm{n}^{\circ}$. 1004/1998, BRASIL, 1998).

\section{Central composite rotatable design (CCRD)}

The preliminary fractional factorial design allowed us to identify the food additives that had a statistically significant effect on cell growth. Using these additives as independent variables, a central composite rotatable design (CCRD) analysis with three replicates at the central point and eight axial points ( $2^{4}$ plus star configuration, with 27 runs) was performed to obtain a second-order model for predicting growth parameters $(\mathrm{A}, \mu, \lambda)$, as a function of the variables studied (concentrations of food additives). The design matrix with the coded and real (i.e., the concentration) values of the independent variables used in the CCRD is shown in Table 3.

\section{Performance of runs of FFD and CCRD}

All runs of FFD and CCRD, described in Tables 1 and 3, respectively, were conducted in $80-\mathrm{mL}$ Erlenmeyer flasks, by adding $1 \%$ of L plantarum (strain CCT 0580, ATCC 8014) inoculum $\left(10^{7} \mathrm{CFU}\right.$ $\mathrm{g}^{-1}$ ), and filling the flasks to the total volume (80 $\mathrm{mL}$ ) with medium (MRS broth). For all runs, the initial $\mathrm{pH}$ of the growth medium was 6.0 (adjusted with $\mathrm{NaOH} 0.1 \mathrm{M}$ ), and the initial water activity varied from 0.93 to 0.95 . Cultures were grown at $35{ }^{\circ} \mathrm{C}$ without shaking, in a Certomat - BS1 incubator (Braun Biotech International, Melsungen, Germany) for approximately 30 hours, depending on experimental conditions (runs). Monitoring of microbial growth was performed by measuring the absorbance at $580 \mathrm{~nm}$ in a FEMTO 700 plus spectrophotometer (FEMTO, São Paulo, Brazil), at intervals of 1 or $2 \mathrm{~h}$. Cultures were monitored until the stationary phase of growth was reached. A trial with inoculant only in additive-free MRS broth was performed as a control treatment in the FFD and in CCRD. The responses of the FFD and CCRD were calculated by using the values for the growth parameters $A, \mathrm{~m}$, and $\lambda$, obtained by fitting growth data to the modified Gompertz predictive model (MGM) (ZWIETERING et al., 1990) represented in equation 1 (below), using the using the STATISTICA 7.0 software (2004 version, Statsoft, Tulsa, USA).

$$
y=A \cdot \exp \left[-\exp \left(\frac{\mu \cdot e}{A} \cdot(\lambda-t)+1\right)\right]
$$

Where: $\mathrm{N}=$ colony-forming units $\left(\mathrm{CFU} \mathrm{g} \mathrm{g}^{-1}\right) ; \mathrm{N}_{0}=$ initial colony-forming units $\left(\mathrm{CFU} \mathrm{g}^{-1}\right) ; \mathrm{y}=\log (\mathrm{N}$ $\left.\mathrm{N}_{\mathrm{o}}^{-1}\right) ; \mathrm{A}=$ logarithmic increase in the population; $\mu$ $=$ maximum specific growth rate $\left(\mathrm{h}^{-1}\right) ; \lambda=$ lag phase duration $(\mathrm{h}) ; \mathrm{t}=$ time $(\mathrm{h})$.

These parameters were used as response (dependent) variables, and were submitted to analysis of variance (ANOVA) and estimation of effects to determine the influence of the independent variables on microbial growth.

\section{Production of new formulations of mortadella and} smoked pork sausage

Based on the results obtained in the analysis of $L$. plantarum growth in culture medium (by fractional factorial design and CCRD) we designed two experimental formulations for each of the meat products (mortadella and smoked pork sausage) with the concentrations of sodium chloride and sodium lactate listed in Table 6. Mortadella and smoked pork sausages were generated at a commercial meat product processing factory, under the same standards used to manufacture similar products. 
Determining the shelf life of mortadella and smoked pork sausages

Mortadella and smoked pork sausages (produced according to experimental or standard formulations) were stored at $30{ }^{\circ} \mathrm{C}$ and $10{ }^{\circ} \mathrm{C}$, respectively. Every three days, one unit of each type of product was removed from storage and prepared for microbiological analysis of LAB counts. For microbiological sample preparation, 25-gram samples of mortadella or smoked pork sausages were collected into sterile procedure bags containing $225 \mathrm{~mL}$ of $0.1 \%$ peptone water $\left(\mathrm{w} \mathrm{v}^{-1}\right)$, homogenized for 60 seconds using a food sample homogenizer (Stomacher - Seward Limited, London, UK). Then, serial dilutions of the homogenate were made (up to $10^{7}$ ) and plated onto a double layer of MRS Agar. Plates were incubated for 48 hours at $30^{\circ} \mathrm{C}$, and then LAB colonies were counted to determine the number of colony-forming units (CFU) per gram of meat product (CFU g ${ }^{-1}$ ) (SILVA et al., 2010). LAB growth on meat products was monitored up to the stationary phase, or until LAB counts $\geq 10^{7} \mathrm{CFU} \mathrm{g}^{-1}$. All samples were performed in duplicate. Following the guidelines established by Slongo et al. (2009), a product was deemed to be at the end of its shelf life when its derived samples yielded LAB counts $\geq 10^{7}$ CFU g ${ }^{-1}$.

\section{Results and Discussion}

Increases in sodium chloride, sodium lactate, garlic, and sodium polyphosphate levels had a negative impact on L. plantarum growth, by FFD

The ultimate goal of our work was to identify a combination of food additives capable of reducing the growth of spoilage bacteria in meat and meat products, thus increasing their shelf life. We first conducted a detailed examination of the effects of selected food additives on the growth (in culture medium) of L. plantarum, a LAB species commonly associated with the spoilage of industrialized meat products (ZHANG et al., 2009; AMMOR et al., 2005). We then used the results of this analysis to establish experimental meat product formulations and to test the shelf life of the products produced under these formulations.

A fractional factorial design (FFD, $2^{5-1}$ ) analysis was applied as an initial step in evaluating the effects of five food additives combined in different concentrations on the growth of $L$. plantarum in MRS broth. Table 1 shows the matrix of the different additive combinations used (19 runs) and the corresponding changes obtained in the responses describing bacterial growth: A (logarithmic increase in the population), $\mathrm{m}$ (specific growth rate), and $\lambda$ (lag phase duration). The modified Gompertz model (MGM) was used to obtain growth parameters in the fractional factorial design.

Table 2 shows estimates of the effects of individual food additives on growth variables, after statistical analysis of the results displayed in Table 1.

The analysis of the response variables showed that changes in the concentrations of sodium chloride, sodium lactate, and garlic had statistically significant effects on the logarithmic increase in the population and on the specific growth rate (Table 2). Importantly, the effects were negative for these responses, within the variable ranges under study (i.e., higher concentrations of sodium chloride, sodium lactate, and garlic led to lower $\mathrm{A}$ and $\mu$ values).

In contrast, the concentrations of sodium chloride, sodium lactate, and sodium polyphosphate had a significant positive effect on lag phase duration (i.e., higher $\lambda$ values were observed with increasing concentrations of sodium chloride, sodium lactate, or sodium polyphosphate, within the ranges under study).

In the concentration range used in this study, sodium nitrite/nitrate did not have a significant effect on the growth of L. plantarum, which is in line with findings by Franco and Landgraf (1996) and Jay (2005). 
Table 1. Results of fractional factorial design (FFD) runs, showing the effects of different food additive combinations on the response variables $(\mathrm{A}, \mu$ and $\lambda$ ) for $L$. plantarum growth in culture medium.

\begin{tabular}{ccccccccc}
\hline Trials & $\mathbf{x}_{\mathbf{1}}$ & $\mathbf{x}_{\mathbf{2}}$ & $\mathbf{x}_{\mathbf{3}}$ & $\mathbf{x}_{4}$ & $\mathbf{x}_{\mathbf{5}}$ & $\mathbf{A}$ & $\boldsymbol{\mu}$ & $\boldsymbol{\lambda}$ \\
\hline 1 & $1(3.3)$ & $1(3)$ & $1(0.5)$ & $1(90)$ & $1(0.40)$ & 1.58 & 0.20 & 9.27 \\
2 & $1(3.3)$ & $1(3)$ & $1(0.5)$ & $-1(10)$ & $-1(0.01)$ & 1.94 & 0.21 & 7.40 \\
3 & $1(3.3)$ & $1(3)$ & $-1(0.1)$ & $1(90)$ & $-1(0.01)$ & 1.90 & 0.25 & 6.26 \\
4 & $1(3.3)$ & $1(3)$ & $-1(0.1)$ & $-1(10)$ & $1(0.40)$ & 1.73 & 0.17 & 6.49 \\
5 & $1(3.3)$ & $-1(1)$ & $1(0.5)$ & $1(90)$ & $-1(0.01)$ & 2.07 & 0.28 & 5.87 \\
6 & $1(3.3)$ & $-1(1)$ & $1(0.5)$ & $-1(10)$ & $1(0.40)$ & 1.79 & 0.25 & 7.16 \\
7 & $1(3.3)$ & $-1(1)$ & $-1(0.1)$ & $1(90)$ & $1(0.40)$ & 1.88 & 0.24 & 5.25 \\
8 & $1(3.3)$ & $-1(1)$ & $-1(0.1)$ & $-1(10)$ & $-1(0.01)$ & 2.09 & 0.27 & 5.25 \\
9 & $-1(1.7)$ & $1(3)$ & $1(0.5)$ & $1(90)$ & $-1(0.01)$ & 2.26 & 0.28 & 4.69 \\
10 & $-1(1.7)$ & $1(3)$ & $1(0.5)$ & $-1(10)$ & $1(0.40)$ & 1.74 & 0.27 & 6.49 \\
11 & $-1(1.7)$ & $1(3)$ & $-1(0.1)$ & $1(90)$ & $1(0.40)$ & 1.85 & 0.28 & 5.67 \\
12 & $-1(1.7)$ & $1(3)$ & $-1(0.1)$ & $-1(10)$ & $-1(0.01)$ & 2.04 & 0.31 & 5.07 \\
13 & $-1(1.7)$ & $-1(1)$ & $1(0.5)$ & $1(90)$ & $1(0.40)$ & 1.90 & 0.35 & 5.40 \\
14 & $-1(1.7)$ & $-1(1)$ & $1(0.5)$ & $-1(10)$ & $-1(0.01)$ & 2.10 & 0.36 & 4.95 \\
15 & $-1(1.7)$ & $-1(1)$ & $-1(0.1)$ & $1(90)$ & $-1(0.01)$ & 2.06 & 0.35 & 4.55 \\
16 & $-1(1.7)$ & $-1(1)$ & $-1(0.1)$ & $-1(10)$ & $1(0.40)$ & 1.95 & 0.25 & 4.03 \\
17 & $0(2.5)$ & $0(2)$ & $0(0.3)$ & $0(50)$ & $0(0.20)$ & 2.06 & 0.27 & 5.18 \\
18 & $0(2.5)$ & $0(2)$ & $0(0.3)$ & $0(50)$ & $0(0.20)$ & 2.01 & 0.25 & 4.94 \\
19 & $0(2.5)$ & $0(2)$ & $0(0.3)$ & $0(50)$ & $0(0.20)$ & 1.90 & 0.27 & 5.54 \\
\hline
\end{tabular}

Results were obtained using a modified Gompertz model (ZWIETERING et al., 1990) applied to the FFD (2 $\left.2^{5-1}\right)$ trials.

$\mathrm{A}=$ logarithmic increase in the population; $\mu=$ maximum specific growth rate $\left(\mathrm{h}^{-1}\right) ; \lambda=$ lag phase duration $(\mathrm{h}) ; \mathrm{x}_{1}=[$ sodium chloride] $(\mathrm{ppm}) ; \mathrm{x}_{2}=$ [sodium lactate $(\mathrm{ppm}) ; \mathrm{x}_{3}=[$ sodium polyphosphate $](\mathrm{ppm}) ; \mathrm{x}_{4}=[$ sodium nitrite/nitrate $](\mathrm{ppm}) ; \mathrm{x}_{5}=[$ powdered garlic $]$ (ppm).

Table 2. Effects of individual food additives on the responses (A, $m$ and $\lambda$ ) obtained using fractional factorial design (FFD) analysis of L. plantarum growth in culture medium.

\begin{tabular}{ccccccccccccc}
\hline & \multicolumn{4}{c}{$\begin{array}{c}\text { Logarithmic increase in the } \\
\text { population }(\mathbf{A})\end{array}$} & \multicolumn{4}{c}{$\begin{array}{c}\text { Maximum specific growth rate } \\
(\boldsymbol{\mu})\end{array}$} & \multicolumn{4}{c}{$\begin{array}{c}\text { Lag phase duration } \\
(\boldsymbol{\lambda})\end{array}$} \\
\hline & $\mathbf{E f f e c t}$ & S.E. & $\mathbf{t}(\mathbf{3})$ & $\mathbf{p}$-value & $\mathbf{E f f e c t}$ & S.E. & $\mathbf{t}(\mathbf{3})$ & $\mathbf{p}$-value & Effect & S.E. & $\mathbf{t}(\mathbf{3})$ & $\mathbf{p}$-value \\
\hline Average & 1.94 & 0.02 & 92.31 & $0.0000^{*}$ & 0.27 & 0.01 & 52.51 & $0.0000^{*}$ & 5.76 & 0.16 & 37.17 & $0.0000^{*}$ \\
$\mathbf{x}_{\mathbf{1}}$ & -0.12 & 0.05 & -2.51 & $0.0261^{*}$ & -0.07 & 0.01 & -6.50 & $0.0000^{*}$ & 1.51 & 0.34 & 4.48 & $0.0006^{*}$ \\
$\mathbf{x}_{\mathbf{2}}$ & -0.10 & 0.05 & -2.18 & $0.0480^{*}$ & -0.05 & 0.01 & -4.26 & $0.0009^{*}$ & 1.11 & 0.34 & 3.29 & $0.0059^{*}$ \\
$\mathbf{x}_{\mathbf{3}}$ & -0.02 & 0.05 & -0.33 & 0.7485 & 0.01 & 0.01 & 0.90 & 0.3866 & 1.08 & 0.34 & 3.20 & $0.0069^{*}$ \\
$\mathbf{x}_{\mathbf{4}}$ & 0.02 & 0.05 & 0.33 & 0.7485 & 0.02 & 0.01 & 1.57 & 0.1409 & 0.02 & 0.34 & 0.04 & 0.9653 \\
$\mathbf{x}_{\mathbf{5}}$ & -0.26 & 0.05 & -5.57 & $0.0001^{*}$ & -0.04 & 0.01 & -3.36 & $0.0051^{*}$ & 0.72 & 0.34 & 2.12 & 0.0542 \\
\hline
\end{tabular}

Results were obtained using a modified Gompertz model (ZWIETERING et al., 1990) applied to the FFD (25-1) trials.

$\mathrm{A}=$ logarithmic increase in the population; $\mu=$ maximum specific growth rate $\left(\mathrm{h}^{-1}\right) ; \lambda=$ lag phase duration $(\mathrm{h}) ; \mathbf{x}_{1}=[\mathrm{sodium}$ chloride $](\mathrm{ppm}) ; \mathrm{x}_{2}=[$ sodium lactate $](\mathrm{ppm}) ; \mathrm{x}_{3}=[$ sodium polyphosphate $](\mathrm{ppm}) ; \mathrm{x}_{4}=[$ sodium nitrite $/$ nitrate $](\mathrm{ppm}) ; \mathrm{x}_{5}=[\mathrm{powdered}$ garlic] $(\mathrm{ppm}) ; \mathrm{S} . \mathrm{E} .=$ standard error. ${ }^{*} \mathrm{p} \leq 0.05$. 
CCRD analysis detected specific interactions between sodium chloride, sodium lactate, and garlic levels and L. plantarum growth parameters

Based on the results obtained using FFD, we used CCRD to evaluate the relationships between $L$. plantarum growth and the concentrations of sodium chloride, sodium lactate, sodium polyphosphate, and garlic only (i.e., excluding sodium nitrite/ nitrate levels) (Table 3, and Figures 1 and 2). The concentration ranges for each food additive used in the analysis with CCRD were selected based on the results from the FFD runs.

Table 3 shows the run matrix of values for independent variables, as well as the values for L. plantarum growth parameters, determined by applying the modified Gompertz model to the growth curves performed for the CCRD analysis.

Table 4 displays the regression coefficients for the evaluated responses describing L. plantarum growth in culture medium.

There was a statistically significant correlation between the concentrations of sodium lactate and garlic, as well as between these variables and the logarithmic increase in the population (Table 4). The only independent variable that had a statistically significant interaction with the specific growth rate $(\mu)$ was the concentration of sodium chloride, while lag phase duration $(\lambda)$ was correlated with the concentration of sodium lactate only. Within the range investigated here, the concentration of sodium polyphosphate had no statistically significant correlation with the response variables evaluated.

In agreement with our results, Park and Kim (2009) reported that the addition of $1 \%$ garlic juice $\left(\mathrm{w} \mathrm{w}^{-1}\right)$ led to decreased peroxide values, residual nitrite, and total microbiological counts compared to controls, in emulsified sausages during cold storage. Also and Drosinos et al. (2006) observed that an initial concentration of $2 \%$ sodium lactate $\left(\mathrm{w} \mathrm{w}^{-1}\right)$ inhibits the development of LAB in meat products without leading to changes in taste. In addition, the same authors indicated that this antimicrobial action might be increased when combined with that of other antimicrobial agents, such as sodium chloride, sodium acetate, and potassium sorbate.

Based on the results from the CCRD runs (Table 4), equations 2, 3, and 4 were generated (by non-linear multiple regression), to estimate the values of microbiological growth parameters for L. plantarum, as a function of the independent variables (food additive concentrations) that had a statistically significant effect on growth (Table 4).

$$
\begin{aligned}
& A=1.6554-0.0420 . X_{2}-0.0185 . X_{2}^{2}-0.0647 . X_{4} \\
& +0.0026 . X_{4}^{2}-0.0494 . X_{2} \cdot X_{4} \\
& \mu=0.1538-0.02170 . X_{1}-0.00046 . X_{1}^{2} \\
& \lambda=5.1114+0.3296 . X_{2}+0.2879 . X_{2}^{2}
\end{aligned}
$$

Where: $X_{1}=$ [sodium chloride (ppm); $X_{2}=[$ sodium lactate $](\mathrm{ppm}) ; \mathrm{X}_{3}=$ [sodium polyphosphate $](\mathrm{ppm})$; $\mathrm{X}_{4=}$ [garlic $](\mathrm{ppm})$.

In equations 2, 3, and 4, the non-significant parameters were incorporated to the residual, for statistical analysis by ANOVA (Table 5). The $\mathrm{F}_{\text {calculated }}$ for regression was greater than the $\mathrm{F}_{\text {tabulated, }}$ indicating that the models were well adjusted to the experimental data, and allowing for the production of response surfaces and contour diagrams for the three response variables analyzed (Figures 1, 2, and 3). 
Table 3. Central composite rotatable design (CCRD) trial results showing the effects of different food additive combinations on the responses for L. plantarum growth in vitro.

\begin{tabular}{cccccccc}
\hline Trials & $\mathbf{x}_{\mathbf{1}}$ & $\mathbf{x}_{\mathbf{2}}$ & $\mathbf{x}_{\mathbf{3}}$ & $\mathbf{x}_{\mathbf{4}}$ & $\mathbf{A}$ & $\boldsymbol{\mu}$ & $\boldsymbol{\lambda}$ \\
\hline 1 & $-1(2.25)$ & $-1(1.00)$ & $-1(0.15)$ & $-1(0.15)$ & 1.71 & 0.19 & 6.14 \\
2 & $-1(2.25)$ & $-1(1.00)$ & $-1(0.15)$ & $1(0.45)$ & 1.63 & 0.18 & 5.18 \\
3 & $-1(2.25)$ & $-1(1.00)$ & $1(0.45)$ & $1(0.45)$ & 1.68 & 0.18 & 5.31 \\
4 & $-1(2.25)$ & $1(3.00)$ & $1(0.45)$ & $1(0.45)$ & 1.47 & 0.17 & 6.11 \\
5 & $-1(2.25)$ & $1(3.00)$ & $-1(0.15)$ & $1(0.45)$ & 1.59 & 0.15 & 5.14 \\
6 & $-1(2.25)$ & $1(3.00)$ & $1(0.45)$ & $-1(0.15)$ & 1.59 & 0.15 & 5.14 \\
7 & $-1(2.25)$ & $-1(1.00)$ & $1(0.45)$ & $-1(0.15)$ & 1.73 & 0.14 & 5.16 \\
8 & $-1(2.25)$ & $1(3.00)$ & $-1(0.15)$ & $-1(0.15)$ & 1.90 & 0.19 & 4.72 \\
9 & $1(3.75)$ & $1(3.00)$ & $1(0.45)$ & $-1(0.15)$ & 1.70 & 0.13 & 6.14 \\
10 & $1(3.75)$ & $1(3.00)$ & $-1(0.15)$ & $-1(0.15)$ & 1.71 & 0.12 & 5.82 \\
11 & $1(3.75)$ & $-1(1.00)$ & $-1(0.15)$ & $-1(0.15)$ & 1.71 & 0.13 & 4.10 \\
12 & $1(3.75)$ & $-1(1.00)$ & $1(0.45)$ & $-1(0.15)$ & 1.80 & 0.15 & 6.00 \\
13 & $1(3.75)$ & $-1(1.00)$ & $-1(0.15)$ & $1(0.45)$ & 1.63 & 0.13 & 4.82 \\
14 & $1(3.75)$ & $1(3.00)$ & $-1(0.15)$ & $1(0.45)$ & 1.53 & 0.11 & 5.79 \\
15 & $1(3.75)$ & $-1(1.00)$ & $1(0.45)$ & $-1(0.15)$ & 1.57 & 0.14 & 6.32 \\
16 & $1(3.75)$ & $1(3.00)$ & $1(0.45)$ & $1(0.45)$ & 1.30 & 0.12 & 5.85 \\
17 & $-2(1.50)$ & $0(2.00)$ & $0(0.30)$ & $0(0.30)$ & 1.65 & 0.21 & 4.71 \\
18 & $2(4.50)$ & $0(2.00)$ & $0(0.30)$ & $0(0.30)$ & 1.60 & 0.11 & 5.73 \\
19 & $0(3.00)$ & $-2(0.00)$ & $0(0.30)$ & $0(0.30)$ & 1.67 & 0.19 & 4.54 \\
20 & $0(3.00)$ & $2(4.00)$ & $0(0.30)$ & $0(0.30)$ & 1.49 & 0.14 & 7.65 \\
21 & $0(3.00)$ & $0(2.00)$ & $-2(0.00)$ & $0(0.30)$ & 1.63 & 0.18 & 6.11 \\
22 & $0(3.00)$ & $0(2.00)$ & $2(0.60)$ & $0(0.30)$ & 1.74 & 0.15 & 4.49 \\
23 & $0(3.00)$ & $0(2.00)$ & $0(0.30)$ & $-2(0.00)$ & 1.75 & 0.21 & 5.56 \\
24 & $0(3.00)$ & $0(2.00)$ & $0(0.30)$ & $2(0.60)$ & 1.59 & 0.13 & 4.48 \\
25 & $0(3.00)$ & $0(2.00)$ & $0(0.30)$ & $0(0.30)$ & 1.62 & 0.16 & 4.90 \\
26 & $0(3.00)$ & $0(2.00)$ & $0(0.30)$ & $0(0.30)$ & 1.67 & 0.15 & 4.53 \\
27 & $0(3.00)$ & $0(2.00)$ & $0(0.30)$ & $0(0.30)$ & 1.67 & 0.15 & 4.47 \\
\hline
\end{tabular}

Results were obtained using a modified Gompertz model (ZWIETERING et al., 1990) applied to CCRD trials.

$\mathrm{A}=$ logarithmic increase in the population; $\mu=$ maximum specific growth rate $\left(\mathrm{h}^{-1}\right) ; \lambda=$ lag phase duration $(\mathrm{h}) ; \mathrm{x}_{1}=$ [sodium chloride $](\mathrm{ppm}) ; \mathrm{x}_{2}=[$ sodium lactate $](\mathrm{ppm}) ; \mathrm{x}_{3}=[$ sodium polyphosphate $](\mathrm{ppm}) ; \mathrm{x}_{4}=$ [powdered garlic $](\mathrm{ppm})$. 
Table 4. Regression coefficients for responses (A,m, and $\lambda$ ) obtained through the modified Gompertz model of the central composite rotatable design (CCRD) trials results.

\begin{tabular}{|c|c|c|c|c|c|c|c|c|c|c|c|c|}
\hline \multirow[b]{2}{*}{ Factors } & \multicolumn{4}{|c|}{$\mathbf{A}$} & \multicolumn{4}{|c|}{$\mu$} & \multicolumn{4}{|c|}{$\lambda$} \\
\hline & RC & S.E. & t (3) & value-p & RC & S.E. & $t(3)$ & value-p & RC & S.E. & $t(3)$ & value-p \\
\hline Average & 1.65 & 0.05 & 33.53 & 0.0000 & 0.15 & 0.01 & 11.84 & 0.0000 & 4.63 & 0.45 & 10.20 & 0.0000 \\
\hline $\begin{array}{l}\text { (1) [sodium } \\
\text { chloride] (L) }\end{array}$ & -0.02 & 0.02 & -1.01 & 0.3302 & -0.02 & 0.00 & -4.62 & $0.0006^{*}$ & 0.11 & 0.17 & 0.68 & 0.5080 \\
\hline $\begin{array}{l}\text { (1) [sodium } \\
\text { chloride] (Q) }\end{array}$ & -0.01 & 0.02 & -0.36 & 0.7259 & 0.00 & 0.00 & 0.11 & 0.9180 & 0.15 & 0.17 & 0.86 & 0.4093 \\
\hline $\begin{array}{l}(2)[\text { sodium } \\
\text { lactate] }(\mathrm{L})\end{array}$ & -0.04 & 0.02 & -2.44 & $0.0314^{*}$ & -0.01 & 0.00 & -1.78 & 0.1001 & 0.38 & 0.17 & 2.32 & $0.0385^{*}$ \\
\hline $\begin{array}{l}\text { (2)[sodium } \\
\text { lactate] }(Q)\end{array}$ & -0.02 & 0.02 & -0.97 & 0.3532 & 0.00 & 0.00 & 0.05 & 645 & 0.36 & 0.17 & 2.13 & 0.0543 \\
\hline $\begin{array}{l}\text { (3)[sodium } \\
\text { phosphate](L) }\end{array}$ & -0.01 & 0.02 & -0.80 & 0.4387 & 0.00 & 0.00 & -0.62 & 0.5500 & -0.01 & 0.17 & -0.06 & 0.9536 \\
\hline $\begin{array}{l}\text { (3)[sodium } \\
\text { phosphate](Q) }\end{array}$ & 0.01 & 0.02 & 0.45 & 0.6582 & 0.00 & 0.00 & 0.33 & 0.7437 & 0.17 & 0.17 & 0.97 & 0.3521 \\
\hline (4) [garlic] (L) & -0.06 & 0.02 & -3.35 & $0.0058^{*}$ & -0.01 & 0.00 & -1.37 & 0.1954 & -0.15 & 0.17 & -0.89 & 0.3886 \\
\hline (4) [garlic] (Q) & 0.00 & 0.02 & 0.18 & 0.8605 & 0.00 & 0.00 & 0.58 & 0.5735 & 0.10 & 0.17 & 0.56 & 0.5848 \\
\hline $1 \mathrm{~L}$ by $2 \mathrm{~L}$ & -0.02 & 0.02 & -0.80 & 0.4412 & 0.00 & 0.01 & -0.47 & 0.6447 & 0.27 & 0.20 & 1.32 & 0.2114 \\
\hline $1 \mathrm{~L}$ by $3 \mathrm{~L}$ & 0.01 & 0.02 & 0.45 & 0.6628 & 0.01 & 0.01 & 1.63 & 0.1298 & 0.12 & 0.20 & 0.59 & 0.5656 \\
\hline $1 \mathrm{~L}$ by $4 \mathrm{~L}$ & 0.00 & 0.02 & -0.09 & 0.9308 & 0.00 & 0.01 & -0.06 & 0.9565 & -0.16 & 0.21 & -0.79 & 0.4475 \\
\hline $2 \mathrm{~L}$ by $3 \mathrm{~L}$ & -0.05 & 0.02 & -2.16 & 0.0521 & 0.00 & 0.01 & 0.21 & 0.8345 & 0.03 & 0.20 & 0.16 & 0.8768 \\
\hline $2 \mathrm{~L}$ by $4 \mathrm{~L}$ & -0.06 & 0.02 & -2.43 & $0.0315^{*}$ & 0.00 & 0.01 & -0.78 & 0.4501 & 0.22 & 0.21 & 1.07 & 0.3060 \\
\hline $3 \mathrm{~L}$ by $4 \mathrm{~L}$ & 0.01 & 0.02 & 0.52 & 0.6122 & 0.01 & 0.01 & 0.42 & 0.1824 & -0.11 & 0.21 & -0.52 & 0.6121 \\
\hline
\end{tabular}

$\mathrm{A}=$ logarithmic increase in the population; $\mu=$ maximum specific growth rate $\left(\mathrm{h}^{-1}\right) ; \lambda=$ lag phase duration $(\mathrm{h})$; RC, Regression coefficient; S.E., standard error. * $\mathrm{p} \leq 0.05$

Table 5. ANOVA of the quadratic model for the prediction of the microbiological parameters A, $\mu$, and $\lambda$.

\begin{tabular}{|c|c|c|c|c|c|c|c|c|c|c|c|c|}
\hline & \multicolumn{4}{|c|}{$\mathbf{A}$} & \multicolumn{4}{|c|}{$\mu$} & \multicolumn{4}{|c|}{$\lambda$} \\
\hline $\begin{array}{l}\text { Variation } \\
\text { Source }\end{array}$ & $\mathbf{S Q}^{\mathbf{a}}$ & $\mathbf{G L}^{\mathbf{b}}$ & $\mathbf{Q M}^{\mathbf{c}}$ & Fcal. $^{\mathrm{d}}$ & SQ & GL & QM & Fcal. & SQ & GL & $\mathbf{Q M}$ & Fcal. \\
\hline Regression & 0.193 & 5 & 0.039 & 5.514 & 0.012 & 2 & 0.006 & 13.090 & 4.811 & 2 & 2 & 4.925 \\
\hline Residual & 0.147 & 21 & 0.007 & & 0.011 & 24 & 0 & & 11.720 & 24 & 24 & \\
\hline Total & 0.340 & 26 & & & 0.023 & 26 & & & 16.530 & 26 & 26 & \\
\hline & \multicolumn{4}{|c|}{$\mathrm{F}_{5 ; 21 ; 0.05}{ }^{\mathrm{e}}=2.6850$} & \multicolumn{4}{|c|}{$\mathrm{F}_{2: 24 ; 0.05}{ }^{\mathrm{e}}=3.4033$} & \multicolumn{4}{|c|}{$\mathrm{F}_{2 ; 24: 0.05}{ }^{\mathrm{e}}=3.4033$} \\
\hline
\end{tabular}

$\mathrm{A}=$ logarithmic increase in the population; $\mu=$ maximum specific growth rate $\left(\mathrm{h}^{-1}\right) ; \lambda=$ lag phase duration (h).

a $\mathrm{SQ}$, sum of squares.

${ }^{\mathrm{b}} \mathrm{GL}$, degrees of freedom.

${ }^{\mathrm{c}} \mathrm{QM}$, mean squares.

${ }^{\mathrm{d}}$ Fcal., F calculated.

${ }^{\mathrm{e}} \mathrm{F}_{2,24 ; 0.05}$, F tabulated. 
According to these diagrams, the concentration of sodium lactate had a negative effect on the logarithmic increase in the population (i.e., increases in the concentration of sodium lactate led to decreases in the response variable A) (Figure 1). This result is in agreement with the work by Drosinos et al. (2006), who investigated the effects of sodium lactate, sodium acetate, and potassium sorbate on the growth of a potential spoilage microorganism, and determined the antimicrobial activity of these preservative agents in meat products to which they were added during product preparation. These authors demonstrated that, in preliminary tests in modified MRS broth, sodium lactate and sodium acetate used as single antimicrobials were more effective than potassium sorbate at inhibiting LAB growth. Increased growth inhibition was also observed when two or three salts were combined (i.e., 3\% sodium lactate, alone or in combination with $0.5 \%$ sodium acetate and $0.15 \%$ potassium sorbate). Finally, when added to the preparation of meat products, the same behavior was observed, and these conditions inhibited lactic bacterial LAB growth during 40 days of storage at $4{ }^{\circ} \mathrm{C}$.

Figure 1. Response surface (A) and contour diagram (B) produced from Central Composite Rotatable Design (CCRD) trial data, showing the effects of sodium lactate and garlic on the logarithmic increase in the population (A) of $L$. plantarum growth in culture media.

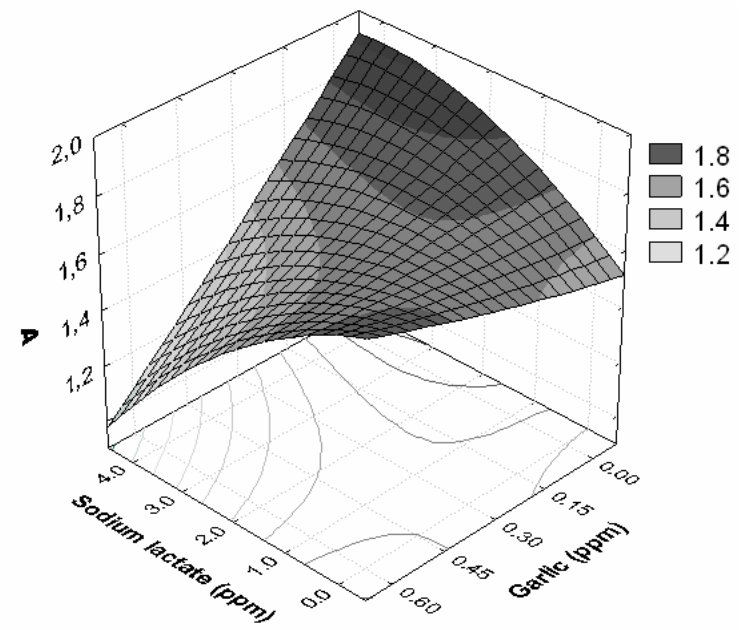

(A)

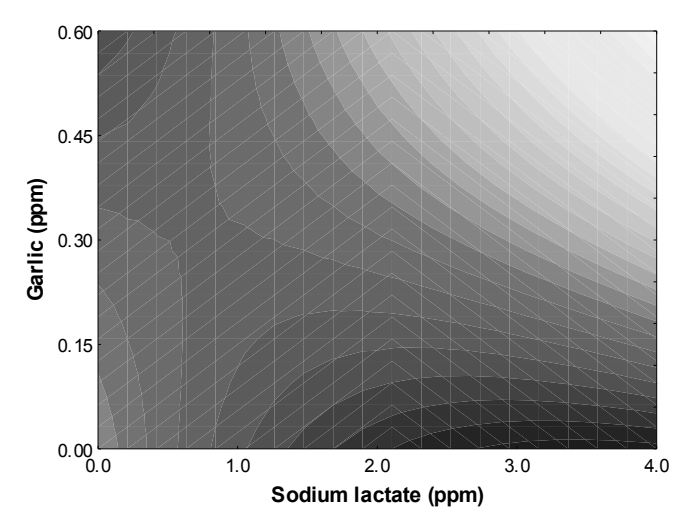

(B) 
Figure 2. Response surface (A) and contour diagram (B) produced from central composite rotatable design (CCRD) trial data, showing the combined effects of sodium lactate and sodium chloride on the specific growth rate (response variable $\mu$ ) of $L$. plantarum in culture media.

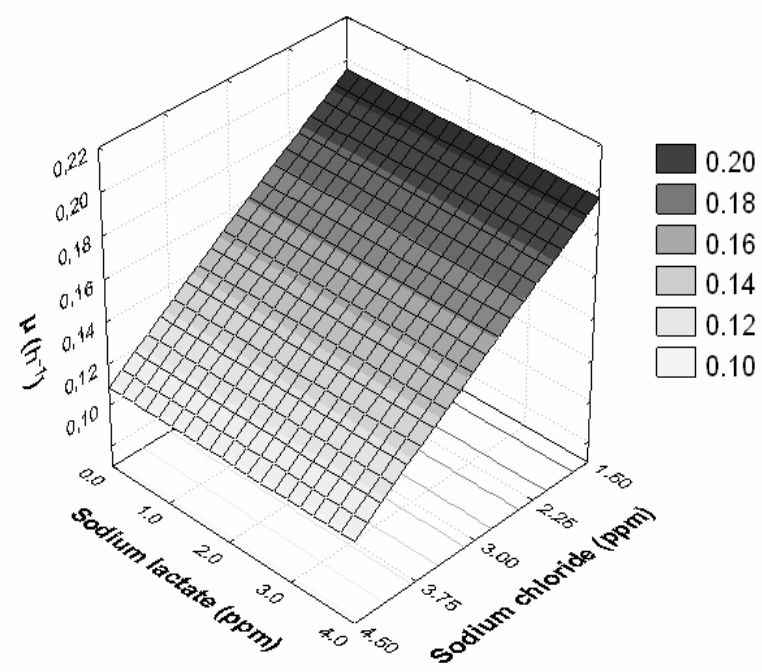

(A)

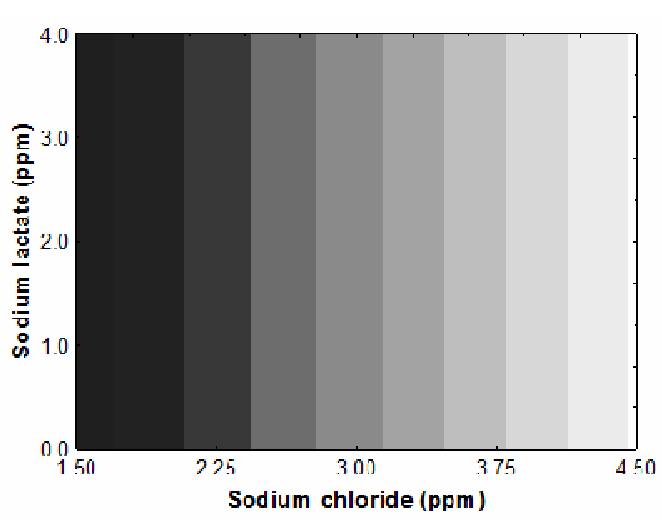

(B)

Figure 3. Response surface (A) and contour diagram (B) produced from central composite rotatable design (CCRD) trial data, showing the combined effects of sodium lactate and sodium chloride on the lag phase duration (response variable $\lambda$ ) of $L$. plantarum growth in culture media.

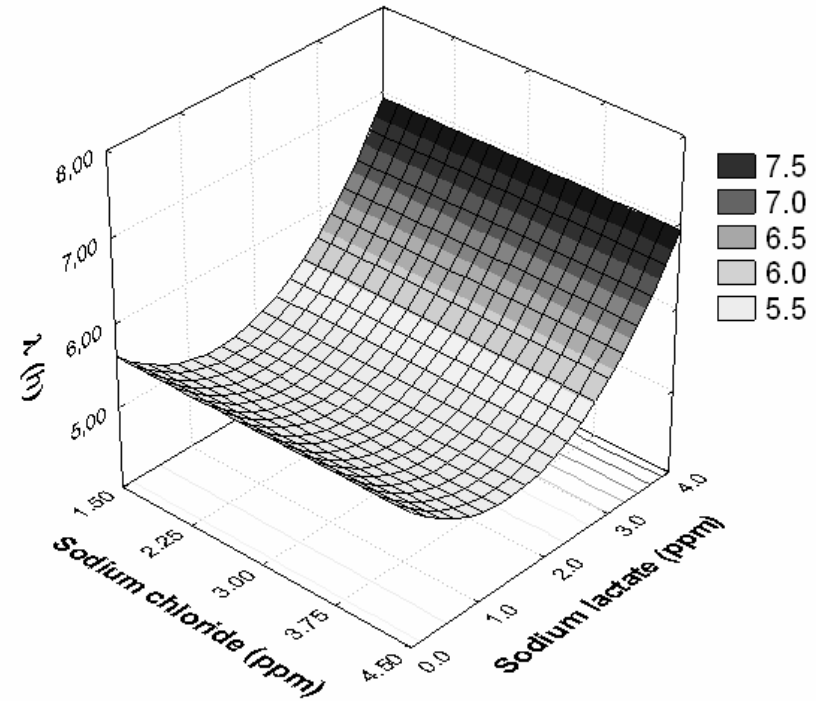

(A)

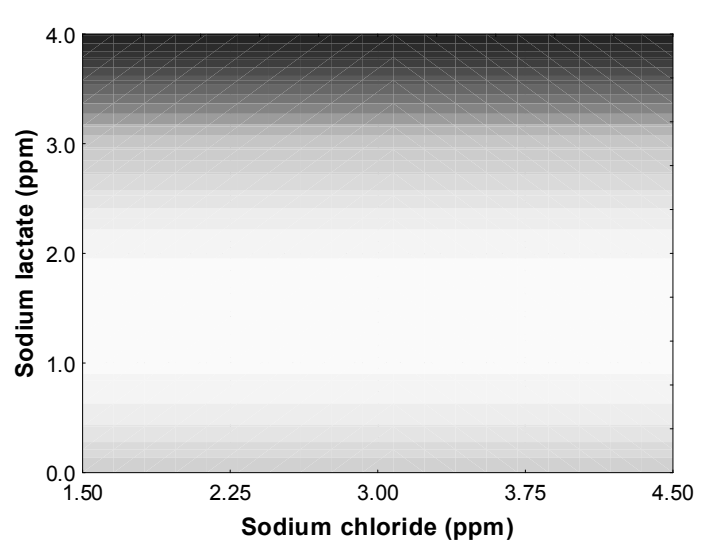

(B)
The concentration of sodium chloride had a negative effect on the specific growth rate (i.e., lower $\mu$ values were observed with increasing concentrations of sodium chloride) but the concentration of sodium lactate had no significant effect on this response variable (Figure 2). $\mathrm{NaCl}$ has long been added to meats as a preservative, for sensory reasons, and to highlight the functional properties of proteins (DESMOND, 2006). The preservative effects of sodium chloride are due to 
its ability to act as a dehydrating agent and to lower the steam pressure of solutions (TAN; SHELEF, 2002). As it interacts with water molecules found in the food, $\mathrm{NaCl}$ makes them unavailable for use by microorganisms (CHIRIFE; RESNICK, 1994), thus reducing water activity.

The concentration of sodium lactate had a positive effect on lag phase duration (i.e., increased $\lambda$ values were observed with higher concentrations of sodium lactate) (Figure 3), in agreement with previous studies (LAMERS, 1996; MACA et al., 1999). Also, the shelf life of meat products can be increased through the addition of lactates (BREWER et al., 1991; PAPADOPOULOS et al., 1991). According to Kitakawa (2002), adding 1.2 $\%$ sodium lactate to fresh mixed sausage led to an extended lag phase of microbial growth, and the combination of this salt with sodium nitrite was an excellent alternative for increasing sausage shelf life. In addition, Sallam et al. (2004) observed that the treatment of ground beef with sodium lactate, alone or in combination with sodium chloride, was effective against the proliferation of aerobic microorganisms, psychrotrophic bacteria, LAB, and Enterobacteriaceae; therefore, the authors concluded that sodium lactate can be used successfully to maintain the chemical quality, reduce the microbial growth, and extend the shelf life of ground beef during refrigerated storage.
Production of new formulations of mortadella and smoked pork sausage

Based on the effects of different additives on LAB growth in culture medium, two formulations of smoked pork sausage and mortadella were produced including the maximum concentration of sodium lactate $(4 \%)$, in combination with lower or higher concentrations of sodium chloride, and these formulations were named "lactate-lower salt" (LLS mortadella and LLS smoked pork sausages) and "lactate-higher salt" (LHS mortadella and LHS smoked pork sausages), respectively (Tables 6 and 7). The concentrations of sodium chloride and sodium lactate used in experimental formulations were chosen based on the FFD and CCRD results, which showed a negative effect for these additives on LAB growth parameters. Thus, the sodium chloride and sodium lactate concentrations used in LLS and LHS products were higher than those found in the standard formulations, but were compliant with the Brazilian legislation, and designed to fulfill the sensory requirements for these meat products. Although sodium nitrite/nitrate levels were not considered for CCRD analysis (since they did not significantly affect LAB growth), these additives were included in the experimental meat product formulations (at concentrations commonly used in the meat processing industry, and in compliance with local legislation) (Tables 6 and 7) due to their ability to inhibit the growth of deteriorating and pathogenic microorganisms, particularly Clostridium botulinum (Sindelar and Milkowski, 2011).

The standard formulation of smoked pork sausages used in the current study was the one routinely used in the meat product processing industry (Table 6). 
Table 6. Concentrations of sodium lactate and sodium chloride used in experimental formulations of smoked pork sausages and in the standard formulation.

\begin{tabular}{lccc}
\hline \multirow{2}{*}{\multicolumn{1}{c}{ Food Additives }} & \multicolumn{3}{c}{ Smoked pork sausage formulations } \\
\cline { 2 - 4 } & Standard $^{\mathrm{a}}$ & LLS $^{\mathrm{b}}$ & LHS $^{\mathrm{c}}$ \\
\hline Sodium chloride (\%) & 1.70 & 2.40 & 3.50 \\
Sodium lactate (\%) & 2.00 & 4.00 & 4.00 \\
Sodium polyphosphate (\%) & 0.20 & 0.20 & 0.20 \\
Sodium nitrite/nitrate (ppm) & 50.00 & 50.00 & 50.00 \\
Powdered garlic (\%) & 0.35 & 0.35 & 0.35 \\
\hline
\end{tabular}

${ }^{a}$ Formulation used regularly in the meat processing industry; ${ }^{\mathrm{b}}$ LLS, "Lactate-lower salt" smoked pork sausages; ${ }^{\mathrm{c}}$ LHS, "Lactatehigher salt" smoked pork sausages. All formulations included $0.1 \%$ monosodium glutamate and $0.2 \%$ sausage condiment.

Table 7. Concentrations of sodium lactate and sodium chloride used in experimental formulations of mortadella and standard formulation.

\begin{tabular}{lccc}
\hline & & Mortadella formulations \\
\hline Food Additives & Standard ${ }^{\text {a }}$ & LLS $^{\mathbf{b}}$ & LHS $^{\mathbf{c}}$ \\
Sodium chloride (\%) & 1.90 & 2.82 & 3.50 \\
Sodium lactate (\%) & 2.00 & 4.00 & 4.00 \\
Sodium polyphosphate (\%) & 0.40 & 0.40 & 0.40 \\
Sodium nitrite/nitrate (ppm) & 50.00 & 50.00 & 50.00 \\
Pasta garlic (\%) & 0.25 & 0.25 & 0.25 \\
\hline
\end{tabular}

${ }^{\mathrm{a}}$ Formulation used in the industry; ${ }^{\mathrm{b}}$ Lactate-lower salt mortadella; ${ }^{\mathrm{c}}$ Lactate-higher salt mortadella. All formulations included $0.05 \%$ monosodium glutamate and $0.5 \%$ mortadella condiment.

Figure 4. Growth of lactic acid bacteria (LAB) in smoked pork sausages prepared according to experimental (LLS and LHS) and standard formulations, and stored at $10{ }^{\circ} \mathrm{C}$.

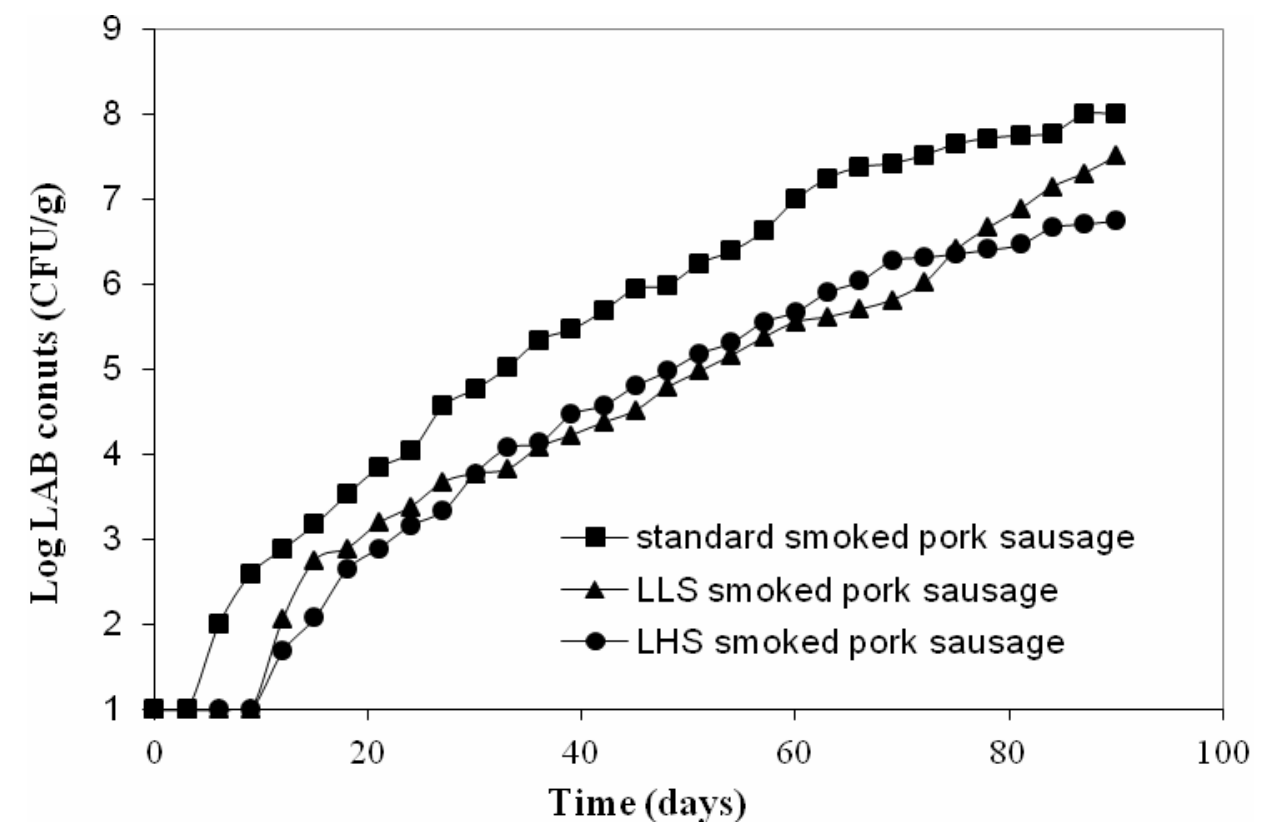

Growth curves were prepared by plating homogenized sausage samples onto MRS Agar, and monitoring LAB growth (by absorbance readings at $580 \mathrm{~nm}$ ) for $48 \mathrm{~h}$ at $30^{\circ} \mathrm{C}$.

LLS, lactate-lower salt; LHS, lactate-higher salt. 
There was a considerable increase (from 3 to 9 days) in the duration of the lag phase of LAB growth from samples of sausages produced under the experimental formulations (both LLS and LHS smoked pork sausages) compared to standard smoked pork sausages (Figure 4). Furthermore, LLS and LHS smoked pork sausages yielded similar LAB growth curves during the evaluated storage time. However, samples from LLS smoked pork sausages yielded LAB cell density counts in the order of $10^{7} \mathrm{CFU} \mathrm{g}^{-1}$ after 82 days of storage (i.e., the product was considered to be at the end of its shelf life), while samples from LHS smoked pork sausages yielded counts of $10^{6} \mathrm{CFU} \mathrm{g}^{-1}$ after 90 days of storage. This behavior was expected, due to the negative effect of $\mathrm{NaCl}$ on water activity, limiting bacterial growth. In contrast, samples from sausages produced under the standard formulation yielded LAB counts of $10^{7} \mathrm{CFU} \mathrm{g}^{-1}$ within 60 days of storage. Therefore, the experimental formulations of smoked pork sausages provided an increase in product shelf life of at least 22 days in comparison to the standard formulation.

These results are in agreement with the observations of Stekelenburg and Kant-Muermans (2001), who reported that the addition of sodium lactate to a cooked ham product, in concentrations between $2.5 \%$ and $3.3 \%\left(\mathrm{w} \mathrm{w}^{-1}\right)$, extended product shelf life, without clear sensory alterations. The same work also showed that sodium lactate inhibited the development of L. monocytogenes in cooked ham products (STEKELENBURG; KANTMUERMANS, 2001).

Figure 5. Growth of lactic acid bacteria (LAB) in mortadella prepared according to experimental (LLS and LHS) and standard formulations, and stored at $30^{\circ} \mathrm{C}$.

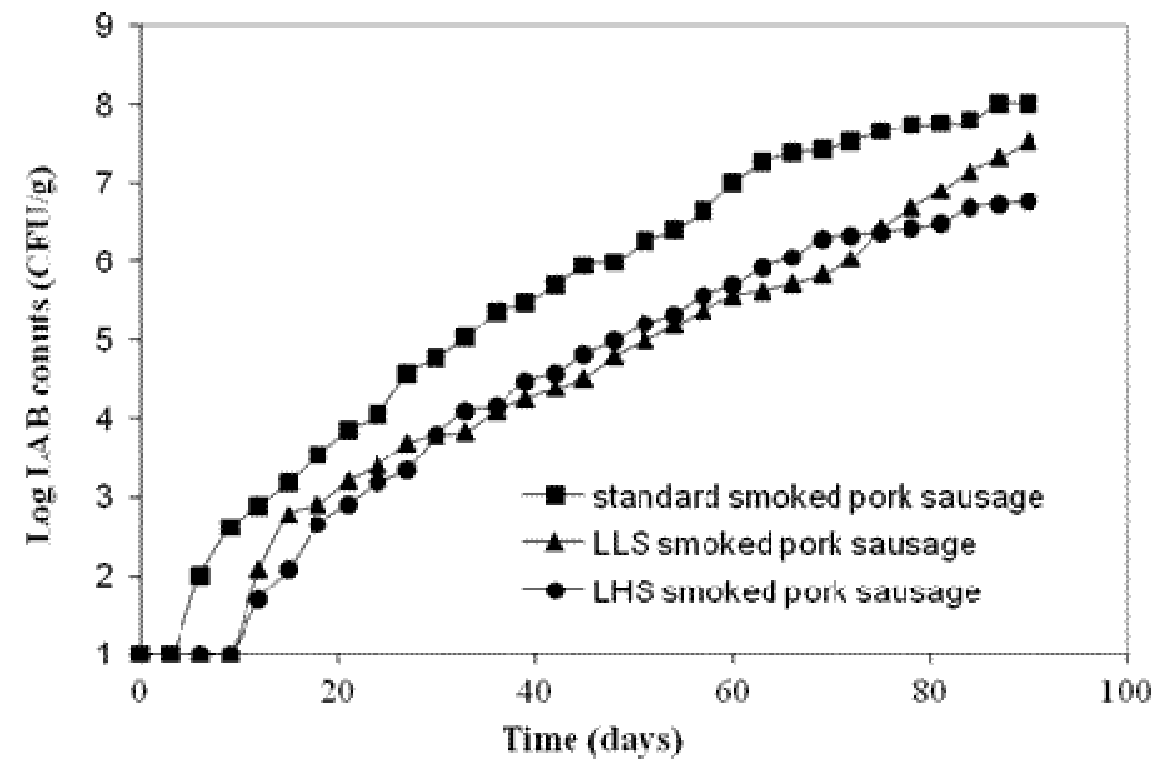

Growth curves were prepared by plating homogenized sausage samples onto MRS Agar, and monitoring LAB growth (by absorbance readings at $580 \mathrm{~nm}$ ) for $48 \mathrm{~h}$ at $30^{\circ} \mathrm{C}$.

LLS, lactate-lower salt; LHS, lactate-higher salt.

Figure 5 shows the growth of lactic acid bacteria in the experimental mortadella formulations (LLS mortadella, LHS mortadella, and standard). The mortadella formulation used as a standard (control) here is routinely used in the meat product processing industry (Table 7).

While the duration of the lag phase of LAB growth in samples of mortadella 2 was 9 days, a 
lag phase of 6 days was observed for samples from mortadella 1 or standard mortadella (Figure 5). Sodium chloride might have contributed to the increase in lag phase duration in cultures from LHS mortadella samples, since the formulation of these products includes a higher concentration of $\mathrm{NaCl}$ compared to that found in LLS mortadella (Table 6). The standard mortadella formulation yielded higher microbial growth than LLS and LHS, with LAB counts approaching $10^{7} \mathrm{CFU} \mathrm{g}^{-1}$ after 60 days of storage at $30^{\circ} \mathrm{C}$ (Figure 5). Both LLS and LHS mortadella formulations yielded approximately the same $\mathrm{LAB}$ count $\left(10^{6} \mathrm{CFU} \mathrm{g}^{-1}\right)$ after 60 storage days at $30^{\circ} \mathrm{C}$, representing an increase in product shelf life compared to the standard formulation. These results can be explained by the ability of sodium chloride to reduce water activity, in addition to its bacteriostatic effect. Moreover, sodium lactate (applied on the formulations at the maximum recommended by the local legislation) can also reduce water activity in meat products (PAPADOPOULOS et al., 1991).

\section{Conclusion}

Our detailed analysis of the effects of different concentrations of five widely used food additives on $L$. plantarum growth showed that, for the concentration ranges used in this study, sodium chloride, lactate, sodium polyphosphates, and garlic (but not sodium nitrite/nitrate) had a negative impact on L. plantarum growth in culture medium. When compared to standard formulations, experimental smoked pork sausage formulations designed according to the $L$. plantarum growth analysis results yielded an increase of at least 22 days in product shelf life (as determined by LAB growth counts from product samples). LAB growth after 60 days of storage in mortadella produced according to experimental formulations were also lower $\left(10^{6} \mathrm{CFU} \mathrm{g}^{-1}\right)$ than those yielded by mortadella produced according to a standard formulation $\left(10^{7}\right.$ $\left.\mathrm{CFU} \mathrm{g}{ }^{-1}\right)$. The results presented here demonstrate that it is possible to use data from bacterial growth in culture medium as a tool to develop new products in the meat product industry.

\section{References}

AMMOR, S.; RACHAMAN, C.; CHAILLOU, S.; PRÉVOST, H.; DOUSSET, X.; ZAGOREC, M.; DUFOUR, E.; CHEVALLIER, I. Phenotypic and genotypic identification of lactic acid bacteria isolated from a small-scale facility producing traditional dry sausages. Food Microbiology, London, v. 22, n. 5, p. 373-382, 2005.

ARVANITOYANNIS, I. S.; STRATAKOS, A. C. Application of modified atmosphere packaging and active/smart technologies to red meat and poultry: a review. Food and Bioprocess Technology, New York, v. 5, n. 5, p. 1423-1446, 2012.

BRASIL. Ministério da Saúde. Regulamento técnico de atribuição de função de aditivos, e seus limites máximos de uso para a categoria 8 - carne e produtos cárneos. Portaria n. 1002/1004, de 11/12/98. Diário Oficial [da] União, n. 239-E, Brasília, 1998. Seção 1, p. 28.

BREWER, M. S.; MCKEITH, F.; MARTIN, S. E.; DALLMIER, A. W.; MEYER, J. Sodium lactate effects on shelf life, sensory, and physical characteristics of fresh pork sausage. Journal of Food Science, Champaign, v. 56, n. 5, p. 1176-1178, 1991.

CAYRÉ, M. E.; GARRO, O.; VIGNOLO, G. Effect of storage temperature and gas permeability of packaging film on the growth of lactic acid bacteria and Brochothrix thermosphacta in cooked meat emulsions. Food Microbiology, London, v. 22, n. 6, p. 505-512, 2005.

CAYRÉ, M. E.; VIGNOLO, G.; GARRO, O. Modelling lactic acid bacteria growth in vacuum-packaged cooked meat emulsions stored at three temperatures. Food Microbiology, London, v. 20, n. 6, p. 561-566, 2003.

CHIRIFE, J.; RESNICK, S. Unsaturated solutions of sodium chloride as reference sources of water activity at various temperatures. Journal of Food Science, Champaign, v. 49, n. 6, p. 1486-1488, 1984.

DABÉS, A. C.; SANTOS, W. L. M.; PEREIRA E. M. Atividade antimicrobiana de bacterias lácticas isoladas de productos cárneos frente a Listeria monocytogenes e Staphylococcus aureus. Arquivo Brasilero de Medicina Veterinaria e Zootecnia, Belo Horizonte, v. 53, n. 1, p. 1-7, 2001.

DESMOND, E. Reducing salt: a challenge for the meat industry. Meat Science, Barking, v. 74, n. 1, p. 188-196, 2006. 
DEVLIEGHERE, F.; GEERAERD, A. H.; VERSYCK, K. J.; BERNAERT, H.; VAN IMPE, J. F.; DEBEVERE, J. Shelf life of modified atmosphere packed cooked meat products:addition of Na-lactate as a fourth shelf life determinative factor in a model and product validation. International Journal Food Microbiology, Amsterdam, v. 58, n. 1-2, p. 93-106, 2000.

DROSINOS, E. H.; MATARAGAS, M.; KAMPANI, A.; KRITIKOS, D.; METAXOPOULOS, I. Inhibitory effect of organic acid salts on spoilage flora in culture medium and cured cooked meat products under commercial manufacturing conditions. Meat Science, Barking, v. 73, n. 1, p. 75-81, 2006.

FRANCO, B. D. G. M.; LANDGRAF, M. Microbiologia dos alimentos. São Paulo: Editora Atheneu, 1996. 182 p.

GLASS, K. A.; GRANBERG, D. A.; SMITH, A. L.; MCNAMARA, A. M.; HARDIN, M.; LADWIG, K. Inhibition of Listeria monocytogenes by sodium diacetate and sodium lactate on wieners and cooked bratwurst. Journal Food Protection, Chicago, v. 65, n. 1, p. 116$123,2002$.

HUGAS, M. Bacteriocinogenic lactic acid bacteria for the biopreservation of meat and meat products. Meat Science, Barking, v. 49, n. 1, p. S139-S150, 1998.

JAY, J. M. Microbiologia de alimentos. São Paulo: ARTEMED Editora S.A., 2005. 771 p.

KHANIPOUR, E.; FLINT, S. H.; MCCARTHY, O. J.; GOLDING, M.; PALMER, J.; TAMPLIN, M. Evaluation of the effects of sodium chloride, potassium sorbate, nisin and lysozyme on the probability of growth of Clostridium sporogenes. International Journal of Food Science \& Technology, Oxford, v. 49, n. 6, p. 1506-1512, 2014.

KITAKAWA, J. H. A. Efeito do lactato de sódio na vida de prateleira de linguiça mista frescal. 2002. Dissertação (Mestrado em Ciência de Alimentos) - Universidade Estadual de Campinas, São Paulo.

KREYEN SCHMIDT, J.; HÜBNER, A.; BEIERLE, E.; CHONSCH, L.; SCHERER, A.; PETERSEN, B. Determination of the shelf life of sliced cooked ham based on the growth of lactic acid bacteria in different steps of the chain. Journal of Applied Microbiology, Oxford, v. 108, n. 2, p. 510-520, 2010.

LAMERS, P. P. Food safety and product development. Fleischwirtschaft, Frankfurt, v. 76, n. 10, p. 1040-1041, 1996.

MACA, J. V.; MILLER, R. K.; BIGNER, M. E.; LUCIA, L. M.; ACUFF, G. R. Sodium lactate and storage temperature effects on shelf life of vacuum packaged beef top rounds. Meat Science, Barking, v. 53, n. 1, p. 23-29, 1999.
MATARAGAS, M.; DROSINOS, E. H.; VAIDANIS, A. Metaxopoulos I. Development of a predictive model for spoilage of cooked cured meat products and its validation under constant and dynamic temperature storage conditions. Journal Food Science, Chicago, v. 71, n. 6, p. M157-M167, 2006.

MBANDI, E.; SHELEF, L. A. Enhanced inhibition of Listeria monocytogenes and Salmonella enteritidis in meat by combinations of sodium lactate and diacetate. Journal of Food Protection, Oxford, v. 64, n. 5, p. 640644, 2001.

MUENCH, L. K.; MADDOCK, R. J.; WULF, D. M. Effects of potential antimicrobial ingredients used to control Listeria monocytogenes on quality of natural casing frankfurters. Meat Science, Barking, v. 80, n. 3, p. 805-813, 2008.

NAKASHIMA, S. M. K.; ANDRÉ, C. D. S.; FRANCO, B. D. G. M. Revisão: aspectos básicos da microbiologia preditiva. Brazilian Journal of Food Technology, Campinas, v. 3, n.1, p. 41-51, 2000.

NUNEZ DE GONZALEZ, M. T.; KEETON, J.T.; ACUFF, G. R. L. J.; RINGER, N.; LUCIA, L. M. Effectiveness of acidic calcium sulphate with propionic and lactic acid and lactates as post processing dipping solutions to control Listeria monocytogenes on frankfurters with or without potassium lactate and stored vacuum packaged at $4.5^{\circ}$ C. Journal Food Protection, Oxford, v. 67, n. 5, p. 915-921, 2004.

OLIVEIRA, K. A. M.; SANTOS-MENDONCA, R. C.; GOMIDE, L. A. M.; VANETTI, M. C. D. Aqueous garlic extract and microbiological quality of refrigerated poultry meat. Journal of Food Processing and Preservation, Westport, v. 29, n. 2, p. 98-108, 2005.

PAPADOPOULOS, L. S.; MILLER, R. K.; ACUFF, G. R.; VANDERZANT, C.; CROSS, H. R. Effect of sodium lactate on microbial and chemical composition of cooked beef during storage. Journal of Food Science, Champaign, v. 56, n. 2, p. 341 347, 1991.

PARK, W. Y.; KIM, Y. J. Effect of garlic and onion juice addition on the lipid oxidation, total plate counts and residual nitrite contents of emulsified sausage during cold storage. Korean Journal for Food Science of Animal Resource, Seoul, v. 29, n. 5, p. 612-618, 2009.

RODRIGUES, M. I.; IEMMA, A. F. Planejamento de experimentos. Campinas: Casa do Pão Editora, 2005. $326 \mathrm{p}$.

RUUSUNEN, M.; PUOLANNE, E. Reducing sodium intake from meat products. Meat Science, Barking, v. 70, n. 3, p. 531-541, 2005. 
SALLAM, K. H.; ISHIOROSHI, M.; SAMEJIMA, K. Antioxidant and antimicrobial effects of garlic in chicken sausage. LWT - Food Science and Technology, London, v. 37 , n. 8 , p. 849-855, 2004.

SAMELIS, J.; KAKOURI, A.; REMENTZIS, J. Selective effect of the product type and the packaging conditions on the species of lactic acid bacteria dominating the spoilage microbial association of cooked meats at $4^{\circ} \mathrm{C}$. Food Microbiology, London, v. 17, n. 3, p. 329-340, 2000.

SILVA, N.; JUNQUEIRA, V. C. A.; SILVEIRA, N. F. A.; TANIWAKI, M. H.; SANTOS, R. F. S.; GOMES, R. A. R.; OKAZAKI, M. M. Manual de métodos de análises microbiológica de alimentos e água. São Paulo: Varela, 2010. Chapter 14.

SINDELAR, J. J.; MILKOWSKI, A. L. Sodium nitrite in processed meat and poultry meats: a review of curing and examining the risk/benefit of its use. American Meat Science Association, Chicago, White Paper Series: 3, 2011.

SLONGO, A. P.; ROSENTHAL, A.; CAMARGO, L. M. Q.; DELIZA, R.; MATHIAS, S. P.; ARAGÃO, G. M. F. Modeling the growth of lactic acid bacteria in sliced ham processed by high hydrostatic pressure. LWT- Food Science and Technology, London, v. 42, n. 1, p. 303-306, 2009.

STATSOFT INC. STATISTICA data analysis software system, version 7, Tulsa.

STEKELENBURG, F. K.; KANT-MUERMANS, M. L. T. Effects of sodium lactate and other additives in a cooked ham product on sensory quality and development of a strain of Lactobacillus curvatus and Listeria monocytogenes. International Journal of Food Microbiology, Amsterdam, v. 66, n. 3, p. 197-203, 2001.

TAN, W.; SHELEF, L. A. Effects of sodium chloride and lactates on chemical and microbiological changes in refrigerated and frozen fresh ground pork. Meat Science, Barking, v. 62, n. 1, p. 27-32, 2002.
TODOROV, S. D.; HO, P.; VAZ-VELHO, M.; DICKS, L. M. T. Characterization of bacteriocins produced by two strains of Lactobacillus plantarum isolated from Beloura and Chouriço, traditional pork products from Portugal. Meat Science, Barking, v. 84, n. 3, p. 334-343, 2010.

VERCAMMEN, A.; VANOIRBEEK, K. G. A.; LURQUIN, I.; STEEN, L.; GOEMAERE, O.; SZCZEPANIAK, S.; PAELINCK, H.; HENDRICKX, M. E. G.; MICHIELS, C. W. Shelf-life extension of cooked ham model product by high hydrostatic pressure and natural preservatives. Innovative Food Science and Emerging Technologies, Amsterdam, v. 12, n. 4, p. 407415, 2011.

VIUDA-MARTOS, M.; RUIZ-NAVAJAS, Y.; FERNANDEZ-LOPEZ, J.; PEREZ-ALVAREZ, J. A. Effect of added citrus fibre and spice essential oils on quality characteristics and shelf-life of mortadella. Meat Science, Barking, v. 85, n. 3, p. 568-576, 2010a.

VIUDA-MARTOS, M.; RUIZ-NAVAJAS, Y.; FERNANDEZ-LOPEZ, J.; PEREZ-ALVAREZ, J. A. Effect of orange dietary fibre, oregano essential oil and packaging conditions on shelf-life of bologna sausages. Food Control, Vurrey, v. 21, n. 4, p. 436-443, 2010 b.

ZHANG, H.; KONG, B.; XIONG, Y. L.; SUN, X. Antimicrobial activities of spice extracts against pathogenic and spoilage bacteria in modified atmosphere packaged fresh pork and vacuum packaged ham slices stored at $4^{\circ}$ C. Meat Science, Barking, v. 81, n. 4, p. 686692, 2009.

ZWIETERING, M. H.; JONGENBURGER, I.; ROMBOUTS, F. M.; VAN'TRIET, K. Modeling of the Bacterial Growth Curve. Appliedd Environmental Microbiology, London, v. 56, n. 6, p. 1875-1881, 1990. 
